\title{
THE EFFECT OF CELEBRITY ENDORSEMENT VIA PERCEIVED VALUE TO PURCHASE INTENTION ON INSTAGRAM
}

\author{
Talitha Febina*, Yuliati Lilik Noor, Kirbrandoko \\ School of Business, Bogor Agricultural University, Indonesia \\ *E-mail: febinatalithadradjat@gmail.com
}

\begin{abstract}
The purpose of this research is to analyze the effect of celebrity endorsement to perceived value on Instagram and to analyze the effect of perceived value to purchase intention on Instagram. The method used in this research was cross sectional design. The data obtained was processed using quantitative approach and carried out by online survey methods to respondents. Data obtained were processed using SEM (Structural Equation Modeling) through AMOS 22 software. The finding revealed celebrity endorsement influenced significantly positive to perceived value [ $t$ count $(9.22)>t$ table $(1.96)]$ and perceived value influenced significantly positive to purchase intention [ $\left.\mathrm{t}_{\text {count }}(10.48)>t \mathrm{t}_{\text {table }}(1.96)\right]$.
\end{abstract}

\section{KEY WORDS}

Celebrity endorsement, Instagram, perceived value, purchase intention.

Indonesia is the third most populous country in the world in which the citizens use internet every day. According to APJII (2016), the total of internet users in Indonesia had reached 51.7 percent of the population in Indonesia in 2016. Based on the Press Release no. 53 of 2018, the total of internet users in Indonesia in 2017 had reached 54.6 percent of the population in Indonesia. This indicated there was a huge increase from 2016 to 2017.

Internet users have several age groups. According to APJII (2017), internet users in Indonesia in 2017 were divided into some groups, such as people in the age group of 13-18 years $(16.68 \%), 19-34$ years $(49.52 \%), 35-54$ years $(29.55) \%)$, and above 54 years $(4.24 \%)$. The biggest internet users belong to the age group of 19-34 years old which included in the millennial generation. An example of internet is social media. According to APJII (2017), social media often used in Indonesia is Instagram (82\%), Facebook (66\%) and Path (49\%).

Instagram was originally a social media used to share photos. As the time goes by, Instagram can be used for business. According to Central Jakarta (2016), there is an increase in the number of sellers on Instagram from past to present. This has led to business competition on Instagram.

Sellers must be able to promote their products well in order to be able to survive on Instagram. The trick is to use the services of celebrity endorsement. In this way it can generate purchase intention in each consumer. This study aims to analyze the influence of celebrity endorsement on purchase intention.

\section{LITERATURE REVIEW}

According to Sumarwan (2011), consumer decision process in buying and consuming goods and services consist of needs recognition, information seeking, alternative evaluations, purchases, and customer satisfaction. According to Sumarwan (2011), the factors that can influence consumer decision processes are marketing strategies, individual differences, and environmental factors.

According to Spry et al. (2011), a celebrity endorsement is an effective promotional tool for product marketing. According to Rossiter and Percy (1997), the dimensions of celebrity endorsement are:

1. Visibility is the popularity of celebrities;

2. Credibility is the expertise that celebrities have about the knowledge of a product that will be advertised and the ability of celebrities to give confidence to consumers; 
3. Attraction is the preferred level (likeability) and the level of similarity with the personality desired by the product user (similarity) where both cannot be separated and must be side by side;

4. Power is the ability of celebrities to attract consumers to buy a product.

According to Lai (2004), perceived value is an overall benefits assessment of products they receive and provide. According to McDoughall and Levesque (2000), perceived value is the difference between the benefits obtained and sacrificed costs.

According to Gefen et al. (2003), buying interest is a situation where consumers are able and intend to be involved in online transactions. According to Puspita (2018), the process of buying interest starts from the emergence of the need for a product to be continued by processing information to evaluate the product.

\section{METHODS OF RESEARCH}

This research used cross sectional design method with the quantitative approach is carried out by online survey methods to respondents. The data was collected from August to September 2018. The respondents were determined by purposive sampling technique. Respondents of this research were 20-35 aged people who bought the latest cosmetic products through Instagram in the last several months. This research used the sample of 200 respondents who bought cosmetics in the last several months. Data processing technique used in this research is SEM (Structural Equation Modeling) with AMOS 22 software and descriptive analysis using SPSS 22.

\section{CONCEPTUAL FRAMEWORK}

Based on empirical studies conducted, it is assumed that celebrity endorsement has an effect on perceived value and perceived value has an effect on purchase intention. The conceptual framework is presented in Figure 1.

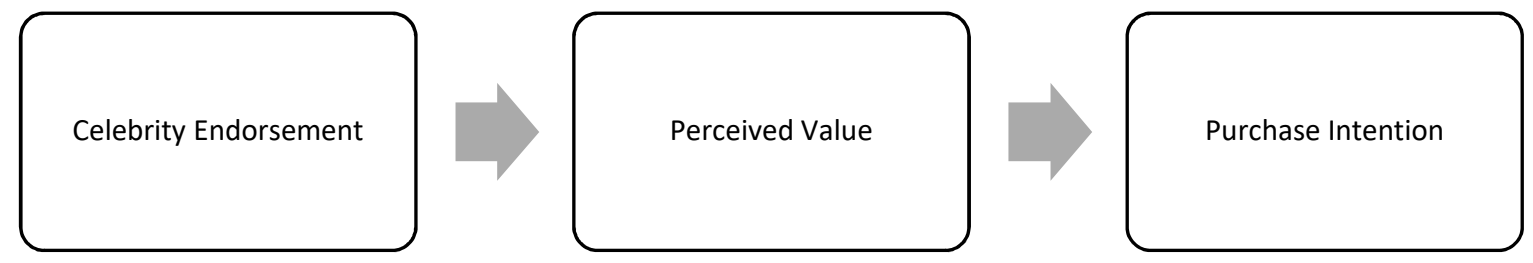

Figure 1 - Conceptual Research Framework

Based on the conceptual framework above, the proposed research hypotheses are celebrity endorsement has an impact to perceived value, and perceived value has an impact to purchase intention.

\section{RESULTS AND DISCUSSION}

Description of Indicator Variables. Description of indicator variables can make it easier to analyze quantitative data and draw conclusions from this study. The following is presented by respondents' answers to the statements that have been submitted in accordance with the top two boxes data processing techniques. The answers were divided into: (1) strongly disagree, (2) disagree, and (3) agree enough to be grouped as disagree and answers (4) agree and (5) strongly agree to be grouped as agree.

Variable of celebrity endorsement consists of four indicators, named visibility (VIS), credibility (CRE), attraction (ATR) and power (POW) while each indicator has three statements. Based on the results of the indicator of visibility for cosmetic products, more than 60 percent respondents agree that it is important to have many followers on their official Instagram account. Around 70 percent respondents agree that they have to recognize 
endorsers through their works. The third statement is having good behavior where 79 percent of respondents said they agreed. It can be concluded that the majority of respondents said they agreed to the visibility indicator of the celebrity endorsement variable.

Based on the results of the indicators of credibility, most respondents agreed that it is important for the seller to be able to promote a product. Half respondents agreed that it is important to be able to attract consumers' attention. Next, more than 60 percent respondents understand that trustworthy in communicating a product is needed. It can be concluded that the majority of respondents agreed to the credibility indicator of the celebrity endorsement variable.

Table 1 - Description of indicator variables celebrity endorsement

\begin{tabular}{|c|c|c|c|}
\hline Symbol & Indicator & $\begin{array}{l}\text { Disagree } \\
(\%)\end{array}$ & $\begin{array}{l}\text { Agree } \\
(\%)\end{array}$ \\
\hline \multirow[t]{3}{*}{ VIS } & Has many followers on their Instagram account & 34.0 & 66.0 \\
\hline & Get to know the endorser through their works & 30.0 & 70.0 \\
\hline & Have good behavior & 21.0 & 79.0 \\
\hline \multirow[t]{3}{*}{ CRE } & Ability to promote a product & 20.0 & 80.0 \\
\hline & The ability to attract the attention of consumers to buy a product & 46.0 & 54.0 \\
\hline & Can be trusted in communicating a product & 39.5 & 60.5 \\
\hline \multirow[t]{3}{*}{ ATR } & Have physical attraction & 20.0 & 80.0 \\
\hline & Able to attract consumers & 22.0 & 78.0 \\
\hline & Able to provide inspiration & 23.0 & 77.0 \\
\hline \multirow[t]{3}{*}{ POW } & Can be emulated & 42.5 & 57.5 \\
\hline & Able to be an idol & 45.5 & 54.5 \\
\hline & Have a career that is successful in advertising products & 31.0 & 69.0 \\
\hline
\end{tabular}

$\%=$ Percentage.

Based on the results of the attraction indicators, the first statement was having physical attractiveness where 80 percent of the respondents said they agreed. The second step is to attract consumers where 78 percent of the respondents said they agreed. The third statement is that it can inspire where 77 percent of respondents said they agreed. It can be concluded that the attraction indicator of the celebrity endorsement variable the majority of respondents said agreed.

Based on the results of the power indicator, the first statement is exemplary where 57.5 percent of the respondents said they agreed. The second term is being able to become an idol where 54.5 percent of respondents said they agreed. The third statement is having a successful career in advertising products where 69 percent of respondents said they agreed. It can be concluded that the power indicator of the celebrity endorsement variable the majority of respondents said agreed.

Table 2 - Description of indicator variables perceived value

\begin{tabular}{llll}
\hline Symbol & Indicator & $\begin{array}{l}\text { Disagree } \\
(\%)\end{array}$ & $\begin{array}{l}\text { Agree } \\
(\%)\end{array}$ \\
\hline PV 1 & Easiness to get information of products on online shopping & 19.5 & 80.5 \\
PV 2 & Using social media can find products that suit your needs & 21.0 & 79.0 \\
PV 3 & Get the benefits of shopping online & 24.5 & 75.5 \\
\hline
\end{tabular}

$\%=$ Percentage.

There are three indicators on perceived value variables. For cosmetic products, most respondents agree that easiness to get information of products on online shopping (PV 1) is much needed. The second indicator is that using social media can find products that are in accordance with needs (PV 2) where 79 percent of respondents say they agree. The third indicator is getting benefits from online shopping (PV 3) where 75.5 percent of respondents 
say they agree. It can be concluded that the indicators of the variable perceived value, the majority of respondents said they agreed.

Table 3 - Description of indicator variables purchase intention

\begin{tabular}{llll}
\hline Symbol & Indicator & Disagree & $\begin{array}{l}\text { Agree } \\
(\%)\end{array}$ \\
\hline MB 1 & Possibility to buy products from sellers & 16.0 & 84.0 \\
MB 2 & Will consider buying products from the seller & 22.5 & 77.5 \\
MB 3 & Intend to buy products from the seller & 20.5 & 79.5 \\
\hline
\end{tabular}

$\%=$ Percentage.

There are three indicators on purchase intention variables. For cosmetic products, the first indicator is the possibility to buy products from sellers (MB 1) where 84 percent of respondents said they agreed. The second indicator is to consider buying products from the seller (MB 2) where 77.5 percent of the respondents said they agreed. The third indicator is intending to buy products from sellers (MB 3) where 79.5 percent of respondents said they agreed. It can be concluded that the indicators of the purchase intention variable, the majority of respondents said agreed.

Overall Model Fit. The model fit test can be seen from GFI, RMSEA, AGFI, TLI, IFI, and CFI. Table 4 showed the overall value of the aspects of the conformity criteria has included the category of Good Fit and Close Fit so that the overall research model is declared feasible.

Table 4 - Overall model fit

\begin{tabular}{llll}
\hline Goodness of Fit & Cut off value & Result & Conclusion \\
\hline Good Fit Index (GFI) & $0.80 \leq$ GFI $<0.90$ or $\geq 0.90$ & 0.95 & Good fit \\
Root Mean Square Error Approximation (RMSEA) & $\leq 0.08$ or $\leq 0.05$ & 0.04 & Close fit \\
Adjusted Good Fit Index (AGFI) & $0.80 \leq A G F I<0.90$ or $\geq 0.90$ & 0.92 & Good fit \\
Tucker Lewis Index (TLI) & $0.80 \leq T L I<0.90$ or $\geq 0.90$ & 0.98 & Good fit \\
Incremental Fit Index (IFI) & $0.80 \leq I F I<0.90$ or $\geq 0.90$ & 0.98 & Good fit \\
Comparative Fit Index (CFI) & $0.80 \leq C F I<0.90$ or $\geq 0.90$ & 0.98 & Good fit \\
\hline
\end{tabular}

GFI (Goodness of Fit Index) is a non-statistical measure that has a range of values between 0 (poor fit) to 1.00 (good fit). GFI has criteria such as the value of $0.80 \leq \mathrm{GFI}<0.90$ is grouped as marginal fit and GFI $\geq 0.87$ is grouped as good fit. Based on the results of the analysis, the GFI value is 0.87 so that the model belongs to the marginal fit category.

According to Ferdinand (2005) RMSEA (Root Mean Square Error Approximation) is an index that can be used to compensate for chi square statistics in large samples. The criteria of RMSEA is the value $\leq 0.08$ is good fit while $\leq 0.05$ is close fit. Based on the results of the analysis, the RMSEA value is 0.07 so that the model is included in the category of good fit.

AGFI (Adjusted Good Fit Index) is the same as GFI but adjusts to the effect of the degree of freedom contained in the model. Based on the analysis results, the AGFI value is 0.83 so that the model belongs to the marginal fit category.

TLI (Tucker Lewis Index) is an incremental conformity index that compares the model tested with the baseline model. The criterion of TLI is the value of 900.90 is good fit, while $0.80 \leq T L I<0.90$ is marginal fit. Based on the results of the analysis obtained a TLI value of 0.90 so that the model belongs to the category of good fit.

IFI (Incremental Fit Index) can be used to overcome parsimony problems and sample sizes. The criteria of the IFI is the value of 0.90 is good fit, while $0.80 \leq \mathrm{IFI}<0.90$ is marginal fit. Based on the results of the analysis, the IFI value is 0.92 so that the model belongs to the category of good fit.

CFI (Comparative Fit Index) is an incremental conformity index. The criteria of CFI is the value of 0.90 is grouped as good fit, while $0.800 . \mathrm{CFI}<0.90$ is marginal fit. Based on the results of the analysis obtained CFI value of 0.92 so that the model belongs to the category of good fit. 
Structural Model Fit. The next step is to test the compatibility of the structural model (structural model fit). The compatibility test of structural equation coefficients of structural equations by specifying a significant level. In this study the significance test used a significance level of 0.05 with a confidence level of $95 \%$. At the 0.05 significance level the $t$ value of each coefficient of the structural equation must be greater than 1.96. The value of $t$ that is smaller than 1.96 indicates that there is a non-significant relationship or cannot explain the latent variable directed by the arrow.

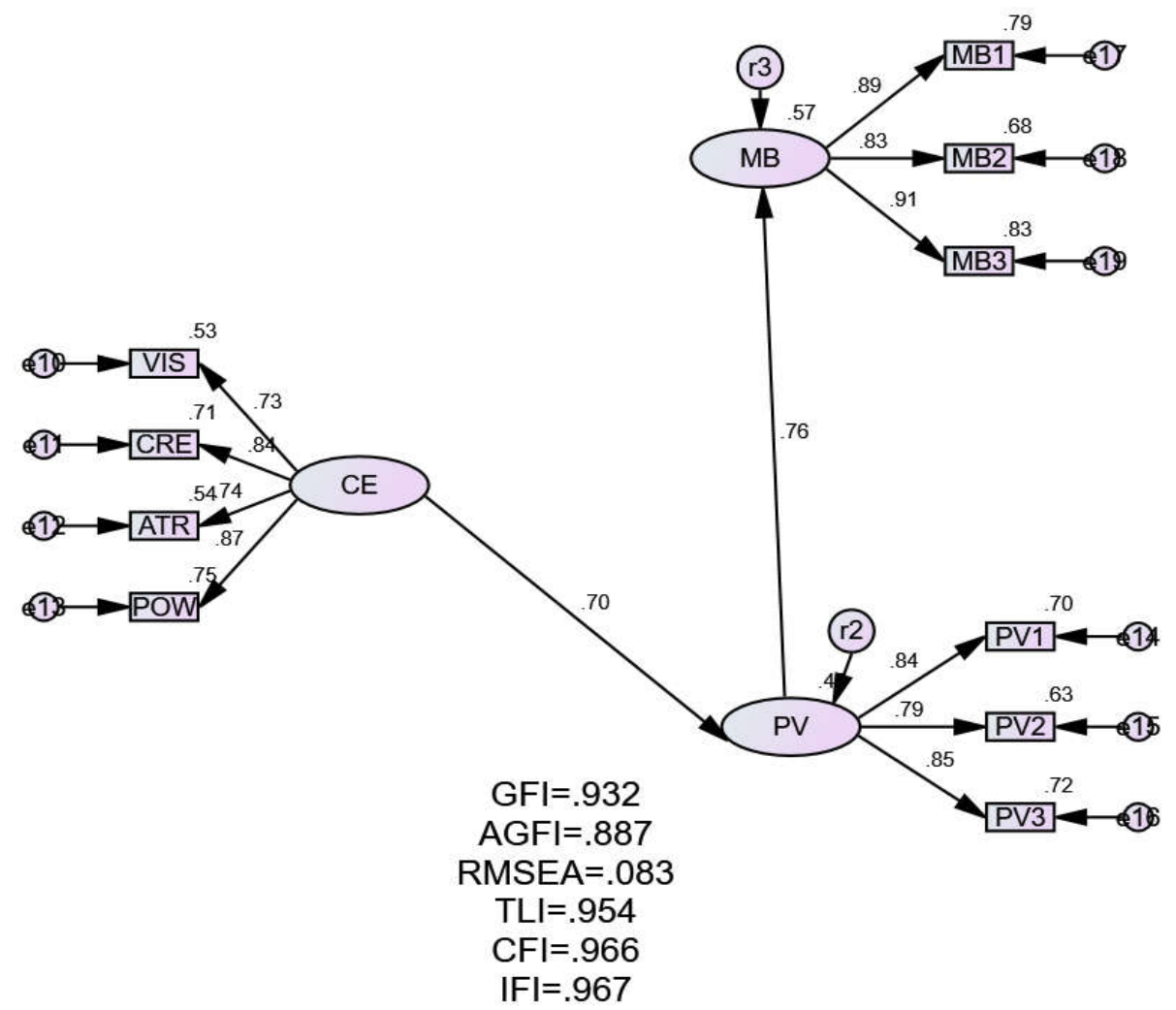

Figure 2 - SEM measurement model on cosmetic products

Figure 2 shows the results of the suitability test of the measurement model on cosmetic products. Based on Figure 2, it can be seen that the hypotheses one, two, three, five, six, and seven are acceptable and significant because the value of $t$ is greater than 1.96. For the fourth hypothesis is rejected and not significant because the value of $t$ is smaller than 1.96.

Indicator Contribution to Variable Celebrity Endorsement. Table 5 shows the value of the loading factor of each indicator against the variable celebrity endorsement. The indicator on the most influential cosmetic products for the variable celebrity endorsement is the power with a loading factor of 0.87 . Power attributes as the biggest contribution to celebrity endorsement means that celebrity has the ability to attract consumers.

A variable is said to be quite consistent if the variable has Construct Reliability (CR)> 0.60 . Table 4 shows that all values of $C R>0.60$. Therefore it can be concluded that the indicators used in this study have good or capable reliability to measure the construct.

Table 5 - Indicator contribution to celebrity endorsement

\begin{tabular}{lll}
\hline Indicator & Loading Factor & CR \\
\hline Visibility & $0.73^{*}$ & 0.87 \\
Has many followers on their Instagram account & \\
Get to know the endorser through their works & \\
Have good behavior & $0.84^{*}$ \\
Credibility & & \\
Ability to promote a product & & \\
\hline
\end{tabular}


Table 5 - Indicator contribution to celebrity endorsement (continue)

\begin{tabular}{ll}
\hline Indicator & Loading Factor \\
\hline The ability to attract the attention of consumers to buy a product & \\
Can be trusted in communicating a product & $0.73^{*}$ \\
Attraction & \\
Have physical attraction & \\
Able to attract consumers & $0.87^{*}$ \\
Able to provide inspiration & \\
Power & \\
Can be emulated & \\
Able to be an idol & \\
Have a career that is successful in advertising products &
\end{tabular}

*Significant $p$-value $<0.05$.

Contribution of Indicators to Perceived Value Variables. Table 6 shows the value of the loading factor of each indicator towards the perceived value variable. The indicator for cosmetic products that has the most influence on the perceived value variable is get the benefits of shopping online with a loading factor of 0.85 . Get the benefits of shopping online attribute as the biggest contribution to perceived value means that consumers benefit from shopping through Instagram.

A variable is said to be quite consistent if the variable has Construct Reliability $(C R)>$ 0.60 . Table 6 shows that all values of $C R>0.60$. Therefore it can be concluded that the indicators used in this study have good or capable reliability to measure the construct.

Table 6 - Indicator contribution to perceived value

\begin{tabular}{lll}
\hline Indicator & Loading Factor & CR \\
\hline Easiness to get information of products on online shopping & $0.84^{*}$ & 0.87 \\
Using social media can find products that suit your needs & $0.79^{*}$ & \\
Get the benefits of shopping online & $0.85^{*}$ & \\
\hline
\end{tabular}

*Significant $p$-value $<0.05$.

Contribution of indicators to variable purchase intention. Table 7 shows the value of the loading factor for each indicator towards the variable of purchase intention. The most influential indicator of cosmetic products on the variable of purchase intention is intending to buy products from the seller. For cosmetic products the value of the loading factor is 0.91 . Intend to buy products from the seller is the biggest contribution to purchase intention means that consumers have the intention to buy more products from sellers on Instagram.

A variable is said to be quite consistent if the variable has Construct Reliability $(C R)>$ 0.60 . Table 7 shows that all values of $C R>0.60$. Therefore it can be concluded that the indicators used in this study have good or capable reliability to measure the construct.

Table 7 - Indicator contributions to purchase intention

\begin{tabular}{lll}
\hline Indicator & Loading Factor & CR \\
\hline Possibility to buy products from sellers & $0.89^{*}$ & 0.91 \\
Will consider buying products from the seller & $0.83^{*}$ & \\
Intend to buy products from the seller & $0.91^{*}$ & \\
\hline
\end{tabular}

*Significant $p$-value $<0.05$.

Hypothesis testing. Based on the empirical model proposed in this study, testing of hypotheses can be done through testing path coefficients in structural equation models estimation results from SEM models of cosmetic products. If the value of the path coefficient $\geq 0.05$ and t-count value 61.96 then the influence of certain variables is included in the significant category but if the path coefficient value $<0.05$ and the value of $t$-count $<1.96$ then the influence between variables is included in the non-significant category. 
Table 8 - Estimation results of the SEM model

\begin{tabular}{lllllll}
\hline Variables effect & & & Path coefficient & t-count & Conclusion & Information \\
\hline Celebrity endorsement & $\rightarrow$ & Perceived value & 0.70 & 9.22 & Significant & Accept \\
Perceived value & $\rightarrow$ & Purchase Intention & 0.76 & 10.48 & Significant & Accept \\
\hline
\end{tabular}

Effect of Celebrity Endorsement Variables on Perceived Value. The effect of the test results resulted in the finding that the third hypothesis for cosmetics products namely celebrity endorsement had a positive and significant effect on perceived value. This can be seen from the celebrity endorsement path coefficient to the perceived value of cosmetic products of 0.70 with a t-value of 9.22 . This can explain that both the celebrity endorsement variable cosmetic products have a positive and significant effect on perceived value, so that the third hypothesis that the celebrity endorsement has a positive and significant effect on perceived value is accepted.

This analysis is also supported by previous studies conducted by Hansudoh (2012) saying that celebrity endorsement has a positive and significant effect on perceived value.

Effect of Variable Perceived Value on Purchase Intention. The results of the testing of the effect resulted in the finding that the sixth hypothesis for cosmetic products, namely perceived value, had a positive and significant effect on purchase intention. This can be seen from the perceived value path coefficient for purchase intention in cosmetics at 0.76 with a tcount value of 10.48. This can explain that both the perceived value of cosmetic products have a positive and significant effect on purchase intention and thus accept the sixth hypothesis which says that perceived value has a positive and significant effect on purchase intention.

This analysis is also supported by previous studies conducted by Shafiq et al. (2011) and Chi et al. (2007) say that perceived value influences purchase intention. In addition, research from Hansudoh (2012) and Eryadi and Yuliana (2016) say that perceived value has a positive and significant effect on purchase intention.

\section{CONCLUSION}

Celebrity endorsement has a positive and significant effect on perceived value so that the hypothesis accepted. This can be concluded from the path coefficient value $\geq 0.05$ and $t-$ count value $\geq 2.00$. Perceived value has a positive and significant effect on purchase intention so that the hypothesis accepted. This is seen from the path coefficient value $\geq 0.05$ and t-count value $\geq 2.00$.

\section{RECOMMENDATIONS}

Suggestions for further research can do research by researching products such as accessories, electronics, culinary, or toys. In addition, it can conduct research through ecommerce such as Shopee, Tokopedia, and Bukalapak.

\section{REFERENCES}

1. [APJII] Asosiasi Penyelenggara Jasa Internet Indonesia. 2016. Time to Become the Principal of Government and Industry Attention. [internet]. [13 April 2018]. Available on: https://apjii.or.id/downfile/file/BULETINAPJIIEDISI05November 2016.pdf.

2. 2017. Productive Age Dominates Internet Users. [internet]. [13 April 2018]. Available on: https://databoks.katadata.co.id/datapublish/2018/02/23/usia-produktif-mendominasipengguna-internet.

3. 2017. Instagram Become the Most Popular Application in Indonesia by Beating Facebook. [internet]. [13 April 2018]. Available on: https://databoks.katadata.co.id/ datapublish/2017/01/13/kalahkan-facebook-instagram-aplikasi-terpopuler-indonesia.

4. Chi H K, Yeh H R, Tsai Y C. 2007. The influence of perceived value on consumer purchase intention: the moderating effect of advertising endorser. 1-6. 
5. Eryadi H T, Yuliana E. 2016. The effect of perceived value and social influence on purchase intention of $4 G$ smartphones in Bandung electronic center customers. Journal of e-Proceeding of Management. 3(1): 86-92.

6. Gefen D, Karahanna E, Straub D W. 2003. Trust and TAM in online shopping: an integrated model. MIS Quarterly. 27(1). 51-90.

7. Hansudoh S A. 2012. The influence of celebrity endorsement on purchase intention through perceived value on Top Coffee products in Surabaya. Jurnal IImiah Mahasiswa Manajemen.

8. Jakpat. 2016. Food buyer on Instagram. [Internet]. [13 April 2018].

9. Lai T L. 2004. Service quality and perceived value's impact on satisfaction, intention and usage of short message service (SMS). Information System Frontiers. 6(4): 353-368.

10. McDougall G H, Levesque T. 2000. Customer satisfaction with services: putting perceived value into the equation. Journal of Service Marketing. 14(5): 392-410.

11. Press Release no. 53. 2018. Communication and Information Technology will continue to accelerate Broadband development. [Internet]. [13 April 2018]. Tersedia pada: https://kominfo.go.id/content/detail/12640/siaran-pers-no-53hmkominfo022018-tentangjumlah-pengguna-internet-2017-me ningkat-kominfo-terus-lakukan-percepatanpembangunanbroadband/0/siar an_pers.

12. Puspita D A. The influence of country of origin, brand image, and marketing mix on the interest in buying Indonesian local bags (studies on Goviyar bags) [thesis]. Bogor (ID): Bogor Agricultural University.

13. Rossiter J R, Percy L. 1997. Advertising and Communication Promotion Management. New York (US): McGraw Hill.

14. Shafiq R, Raza I, Rehman M Z. 2011 Analysis of the factors affecting customers' purchase intention: the mediating role of perceived value, African. Journal of Business Management. 5(26).

15. Spry A, Pappu R, Cornwell T B. 2011. Celebrity endorsement, brand credibility and brand equity. European Journal of Marketing. 45(6): 882-909.

16. Sumarwan U. 2011. Consumer Behaviour: Theory and Applied Marketing. Bogor (ID): Ghalia Indonesia. 